\title{
Beneficial effects of traditional Chinese medicine Wuzhi Capsule on tacrolimus dose requirements in liver transplant patients with different donor-recipient CYP3A5 genotypes
}

Kai Kou

Jilin University First Hospital

Xiaodong Sun

Jilin University First Hospital

Mingqian Li

Jilin University First Hospital

Ting Li

Jilin University First Hospital

Yuelei Hu

Jilin University First Hospital

Shuxuan Li

Jilin University First Hospital

Guoyue Lv ( $\sim$ lvgy@jlu.edu.cn )

Jilin University First Hospital https://orcid.org/0000-0002-0140-7895

Research

Keywords: Wuzhi Capsule, cytochrome P-450 3A5, liver transplantation, Tacrolimus

Posted Date: March 19th, 2021

DOI: https://doi.org/10.21203/rs.3.rs-325961/v1

License: (9) (1) This work is licensed under a Creative Commons Attribution 4.0 International License. Read Full License 


\section{Abstract}

Background/Aims: Tacrolimus (Tac) is an immunosuppressant that is widely used to prevent allograft rejection in patients after liver transplantation. Recently, a Chinese herbal medicine known as Wuzhi Capsule (WZC) was shown to increase Tac blood concentrations by inhibiting the activity of CYP3A5 in animal studies in rats. To date, it remains unexplored whether WZC can be used to reduce the dose requirement for Tac in liver transplant patients with different donor-recipient CYP3A5 genotypes.

Materials and Methods: A total of 185 liver transplant patients were enrolled and were divided into four groups according to the combinations of donor-recipient CYP3A5 phenotypes. WZC was given to patients who had C0/D of Tac $\leq 1 \mathrm{ng} / \mathrm{ml} \mathrm{per} \mathrm{mg}$ and required a dose of $\mathrm{Tac} \geq 4 \mathrm{mg}$.

Results: The R+/D+ group had the lowest C0, C0/D, and C0/D/W among the four groups. Furthermore, a larger proportion of patients in the CYP3A5 expression groups required Tac dose adjustment to achieve a therapeutic effect and were given Tac with WZC. Notably, the use of WZC significantly increased the blood concentrations of Tac in the CYP3A5 expression groups.

Conclusion: WZC significantly increased the $\mathrm{CO}, \mathrm{CO} / \mathrm{D}$, and C0/D/W in the CYP3A5 expression groups.

\section{Introduction}

Liver transplantation (LT) is currently the only curative treatment for patients with end-stage liver disease. After LT, patients commonly require oral immunosuppressive agents as anti-rejection therapy to prevent allograft rejection. Tacrolimus (Tac) is widely used in most immunosuppressive regimes for LT patients mainly due to its high immunosuppressive effects and low drug-related side effects (6-8). However, both rejection of the transplanted liver and Tac-related adverse effects occur after LT in a proportion of patients. This is primarily because the therapeutic margin of Tac is very narrow and its metabolic enzyme, cytochrome P450 3A5 (CYP3A5), has different genetic variants (1). These factors have a significant impact on the pharmacokinetics of Tac and thereby affect the required dose of Tac for LT patients. In clinical practice, the Tac dose needs to be adjusted frequently according to its blood trough concentration (C0) in LT patients to achieve a therapeutic effect on postoperative rejection and to avoid drug toxicity. A number of previous studies have shown that higher doses of Tac are associated with side effects, such as liver and kidney toxicity, tumor promotion and progression, and increased risk for diabetes (2-5). Therefore, there is an urgent need to reduce the Tac dose while maintaining the therapeutic effect in patients who undergo LT.

Recently, a Chinese herbal medicine named Wuzhi Capsule (WZC) was demonstrated to increase Tac blood levels in animal studies through suppressing the enzymatic activity of CYP3A5 in rats. WZC is made from Schisandra sphenanthera, also known as Nan-Wuweizi, and is an effective treatment for alleviating liver damage with various etiological factors (e.g. hepatoxins, viral hepatitis) $(9,10)$. It has been demonstrated that WZC inhibits the P glycoprotein-mediated efflux of Tac and CYP3A-mediated metabolism of Tac, leading to an increase in the oral bioavailability and blood concentration of the drug (11). In recent years, WZC has been prescribed for patients after solid organ transplantation in many transplant centers in China. However, no study on the clinical application of WZCs in LT patients with different combinations of donor-recipient CYP3A5 genotypes has been conducted. To date, it remains unexplored whether WZC can exert similar effects and can be used to reduce the dose requirements for Tac in LT patients.

Intrigued by and building upon the findings regarding Tac in animal studies, we performed the first human study to assess the effects of WZC on Tac blood concentrations in the early phase post LT in patients with different combinations of donorrecipient CYP3A5 genotypes. The findings from this study may improve anti-rejection therapy for patients after LT.

\section{Materials And Methods}

\section{Patients}


During the period between 2017 and 2020, More than 200 patients received liver transplants from brain-dead donors and were given a triple immunosuppressive regimen based on calcineurin inhibitors (Tac, mycophenolate mofetil, methyl ketone) in the First Hospital of Jilin University (Changchun, Jilin, China) were screened for eligibility. Of these patients, 185 were enrolled in this study. The key eligibility criteria were as follows: (1) Aspartate transferase (AST) and alanine transferase (ALT) less than 10 times the upper limit of normal (ULN) values within 2 week after surgery; and (2) Survival greater than 6 months. Patients who met the following criteria were excluded from this study: (1) Taking other drugs known to affect the dose requirements of Tac, such as diltiazem, fluconazole, and rifampin; (2) Occurrence of acute rejection, abdominal hemorrhage, and severe abnormal function of the liver caused by biliary stricture within 3 months; (3) Taking other immunosuppressive agents (e.g. cyclosporin A, sirolimus).

Prior to the study, all participants provided written informed consent. The clinical study was carefully reviewed and approved by the Ethics Committee of the First Hospital of Jilin University.

\section{Treatments and measurements of Tac blood levels}

The patients began taking Tac on the second day after LT. The initial dose of Tac was 2-3 mg, the target C0 measured prior to the first dose of Tac $(\mathrm{t}=0)$ was $5-10 \mathrm{ng} / \mathrm{ml}$, and the dose of Tac was subsequently adjusted according to $\mathrm{C} 0$. When the dose of Tac was $\geq 4 \mathrm{mg}$ and the dose-adjusted CO (CO/D) of Tac measured twice in succession was $\leq 1 \mathrm{ng} / \mathrm{ml}$ per $\mathrm{mg}$, WZC was given, starting with a dose of $0.5 \mathrm{~g}$ and increasing the dose as appropriate according to the $\mathrm{CO}$.

Tac blood levels were monitored and quantified using an automatic enzyme immunoassay analyzer (Siemens Pro-E, Germany) according to the manufacturer's instructions. Given that the area under the Tac concentration-time curve (AUC) has a good correlation with the trough level $(13,14)$, the $\mathrm{C} 0$ before the first dose of Tac can accurately reflect the metabolism of the drug.

CO/D was calculated by dividing the $\mathrm{CO}(\mathrm{ng} / \mathrm{ml})$ with the 24-h Tac dose $(\mathrm{mg})$. the dose- and body weight-adjusted C0 (CO/D/W) was calculated by dividing the $\mathrm{CO}(\mathrm{ng} / \mathrm{ml})$ with the 24-h Tac dose per kilogram (mg/kg), and Tac C0, CO/D, and CO/D/W on days 7 and 14 after LT were calculated for further analysis.

\section{Clinical laboratory tests}

Biochemical examinations were performed to determine liver function. The tests included AST, ALT, bilirubin, and albumin. In addition, blood routine (hemoglobin), renal function (creatinine), and weight were measured on days 7 and 14 after surgery.

CYP3A5 genotypes of liver transplant recipients and donors

Genotyping of CYP3A5 was performed in the LT recipients and donors. Based on the combinations of recipient-donor CYP3A5 genotypes, the 185 patient were divided into the following four groups: (1) recipient (R)+/Donor (D) + group [recipient expression $\left(1^{*}\right)$ /donor expression ( $\left.1^{*}\right), n=47$ ], (2) R+/D- group [recipient expression (1*)/donor non-expression $\left.\left(3^{*}\right), n=48\right],(3)$ $\mathrm{R}$-/D + group [recipient non-expression (3*)/donor expression( $\left.1^{*}\right), \mathrm{n}=45$, and R-/D- group [recipient non-expression $\left(3^{\star}\right) /$ donor non-expression $\left(3^{\star}\right), \mathrm{n}=45$ ]. The CO $(\mathrm{ng} / \mathrm{ml}), \mathrm{CO} / \mathrm{D}(\mathrm{ng} / \mathrm{ml}$ per $\mathrm{mg})$, and C0/D/W $(\mathrm{ng} / \mathrm{ml} \mathrm{per} \mathrm{mg} / \mathrm{kg})$ were compared and analyzed on days 7 and 14 after LT.

\section{Statistical analysis}

All data were analyzed using the statistical software SPSS25. For continuous data, the Kolmogorov Smirnov test was performed to determine whether the data had a normal distribution. Normally distributed data, such as age and weight, were expressed as mean \pm standard deviation $(x \pm s)$. Non-normally distributed data were presented in median and quarter points; that is, the "median (quartile)" M (Q1-Q3) means was used for data such as the recipient's liver function (including: AST, ALT, bilirubin, albumin), blood test (hemoglobin), and renal function (creatinine) results. Categorical variables (e.g. gender, blood type) were expressed as frequency and the chi-square test was used for comparisons. For data with a normal distribution and homogeneity of variance, one-way analysis of variance and the Student-Newman-Keuls (SNK) test were used to perform multiple comparisons between groups. The Kruskal-Wallis test was used for continuous variables with a non-normal distribution or uneven variance, such as $\mathrm{C} 0, \mathrm{CO} / \mathrm{D}, \mathrm{CO} / \mathrm{D} / \mathrm{W} . \mathrm{P}<0.05$ was considered statistically significant between groups.

\section{Results}




\section{Baseline characteristics of liver transplant patients}

A total of 185 LT patients were enrolled in this study, of which 138 (74.59\%) were men and 47 (25.41\%) were women. The baseline demographics, clinical characteristics, and laboratory tests results are summarized in Table 1. The mean age of the patients was $52.8 \pm 9.9$ years. The patients had different donor-recipient CYP3A5 genotypes, according to which they were divided into four groups: $R+/ D+$ group $(n=47), R+/ D$ - group $(n=48), R-/ D+$ group $(n=45)$, and R-/D- group $(n=45)$. Statistical analysis revealed no significant differences in the baseline characteristics between the groups $(P>0.05)($ Table 1$)$.

\section{Effects of recipient-donor CYP3A5 genotypes on Tac blood concentrations}

Tac blood concentrations, represented by C0, C0/D, and C0/D/W, were compared between the groups with different combinations of recipient-donor CYP3A5 genotypes and the resulting data are shown in Tables 2 and 3. On day 7, the C0 was $5.600 \mathrm{ng} / \mathrm{ml}$ in the R+/D + group, which was significantly lower than the corresponding values of $7.900 \mathrm{ng} / \mathrm{ml}$ in the R-/Dgroup $(P<0.001)$ and $7.350 \mathrm{ng} / \mathrm{ml}(P=0.002)$ in the $R+/ D$ - group. On day 14 , the $C 0$ in the $R+/ D+$ group was significantly lower than that in the R-/D- group $(P=0.005)$.

A similar comparison was performed for CO/D between the groups. The R+/D + group had significantly lower C0/D than the corresponding levels in the R+/D- group ( $P<0.001)$, the R-/D + group, and the R-/D-group $(P<0.001)$. On day 14 , the C0/D in the R-/D- group was $1.940 \mathrm{ng} / \mathrm{ml}$ per $\mathrm{mg}$, which was significantly higher than those in the $R+/ D+$ group $(P<0.001)$, the $R+/ D$ $(P=0.003)$, and the $R-/ D+$ group $(P<0.001)$.

In terms of C0/D/W, the R+/D + group had a mean level of $63.600 \mathrm{ng} / \mathrm{ml} \mathrm{per} \mathrm{mg} / \mathrm{kg}$, which was significantly lower than the levels in the $R+/ D$ - group $(P=0.006)$, the $R-/ D$ + group $(P=0.003)$, and the $R-/ D$ - group $(P<0.001)$. On day 14 , the $C 0 / D / W$ in the R-/D- group was $129.000 \mathrm{ng} / \mathrm{ml}$ per $\mathrm{mg} / \mathrm{kg}$, which was significantly higher than that in the $\mathrm{R}+/ \mathrm{D}+\mathrm{group}(\mathrm{P}<0.001)$, the $R+/ D$ - group $(P=0.007)$, and the $R-/ D+$ group $(P=0.012)$.

\section{Effects of WZC on early blood concentrations of Tac in patients with different combinations of donor- recipient CYP3A5 genotypes}

The effects of WZC on the early blood concentrations of Tac (e.g. C0, C0/D, and C0/D/W) were assessed in the enrolled participants with different combinations of recipient-donor CYP3A5 genotypes and the results are summarized in Tables 4 and 5. Among the 185 LT patients, 153 (82.70\%) did not require WZC on day 7 and were characterized as the Non-WZC group. The $32(17.30 \%)$ patients that required WZC on day 7 were characterized as the WZC group. Notably, $112(60.54 \%)$ patients remained in the Non-WZC group on day 14, with 73 (39.46\%) in the WZC group. The patients in the Non-WZC and WZC groups were further divided into four subgroups according to the difference in the donor-recipient CYP3A5 genotypes. The differences in $\mathrm{CO}, \mathrm{CO} / \mathrm{D}$, and CO/D/W were compared between the groups on days 7 and 14 following LT.

On day 7, the $C 0$ of patients who did not require WZC in the R+/D + group was $5.300 \mathrm{ng} / \mathrm{ml}$, which was significantly lower than the corresponding values of $7.800 \mathrm{ng} / \mathrm{ml}$ in the $\mathrm{R}$-/D- group $(P<0.001), 7.000 \mathrm{ng} / \mathrm{ml}$ in the $\mathrm{R}+/ \mathrm{D}$ - group $(P=0.007)$, and 5.600 $\mathrm{ng} / \mathrm{ml}$ in the R-/D + group. There was no significant difference in CO between the four groups among those who received WZC on day $7(P=0.212)$. The $C 0$ of patients who did not require $W Z C$ on day 14 in the $R+/ D+$ group was $6.200 \mathrm{ng} / \mathrm{ml}$, which remained significantly lower than the values in the $R$-/D- group $(P=0.009)$ and $R-/ D+$ group. There was no significant difference in the $\mathrm{C} 0$ between the four groups with different combinations of recipient-donor CYP3A5 genotypes among patients who were treated with WZC on day $14(\mathrm{P}=0.166)$.

Among patients who did not require WZC on day 7, the C0/D in the R+/D + group was $0.993 \mathrm{ng} / \mathrm{ml}$ per mg, which was significantly lower than the corresponding values in the $R+/ D$ - group $(P=0.002), R-/ D+$ group $(P=0.003)$, and $R-/ D$ - group $(P<$ 0.001). There was no significant difference in the CO/D between the four groups among patients who received WZC on day 7 $(P=0.138)$. The CO/D in the R-/D- group of patients who did not receive WZC on day 14 was $1.940 \mathrm{ng} / \mathrm{ml}$ per mg, significantly higher than the values in the $R+/ D+$ group $(P<0.001)$, the $R+/ D$ - group $(P=0.021)$, and the $R-/ D+$ group $(P<0.001)$. The C0/D in the R-/D- group of patients who received WZC on day 14 was $1.912 \mathrm{ng} / \mathrm{ml}$ per $\mathrm{mg}$, significantly higher than that in the R+/D $+\operatorname{group}(P=0.013)$. 
Among patients who did not require WZC on day 7, the C0/D/W in the R+/D + group was $63.575 \mathrm{ng} / \mathrm{ml} \mathrm{per} \mathrm{mg} / \mathrm{kg}$, which was significantly lower than the corresponding values of $87.111 \mathrm{ng} / \mathrm{ml} \mathrm{per} \mathrm{mg} / \mathrm{kg}(\mathrm{P}=0.008)$ in the $\mathrm{R}+/ \mathrm{D}$ - group, $87.500 \mathrm{ng} / \mathrm{ml} \mathrm{per}$ $\mathrm{mg} / \mathrm{kg}(\mathrm{P}=0.007)$ in the $\mathrm{R}-/ \mathrm{D}+$ group, and $113.600 \mathrm{ng} / \mathrm{ml} \mathrm{per} \mathrm{mg} / \mathrm{kg}(P<0.001)$ in the R-/D- group. There was no significant difference between the four groups among patients who received WZC on day $7(P=0.378)$. The $C 0 / D / W$ among patients who received WZC on day 14 in the R-/D- group was 129.000, which was significantly higher than that in the $R+/ D+$ group 61.600 $\mathrm{ng} / \mathrm{ml}$ per $\mathrm{mg} / \mathrm{kg}(\mathrm{P}<0.001)$, as well as the corresponding values of $88.280 \mathrm{ng} / \mathrm{ml} \mathrm{per} \mathrm{mg} / \mathrm{kg}(\mathrm{P}=0.036)$ in the $\mathrm{R}+/ \mathrm{D}$ - group and $77.100 \mathrm{ng} / \mathrm{ml}$ per $\mathrm{mg} / \mathrm{kg}(P=0.002)$ in the $\mathrm{R}-/ \mathrm{D}+$ group. There was no significant difference among the four groups among patients who received WZC on day $14(\mathrm{P}=0.098)$.

\section{Self-control analysis of effects of WZC on Tac blood concentrations}

To further evaluate the beneficial effects of WZC on Tac blood concentrations, the LT patients were divided into four subgroups based on whether and when WZC was orally administrated (Table 6). 112 (60.54\%) patients did not receive WZC on days 7 and 14 after LT (A), 20 (10.81\%) were given WZC on both days 7 and 14 after LT (B), 41 (22.16\%) received WZC only on the 14th day after LT (C), and $12(6.49 \%)$ received WZC on the 7th day, with a higher dose on the 14th day after LT. The CO, $\mathrm{CO} / \mathrm{D}$ and $\mathrm{CO} / \mathrm{D} / \mathrm{W}$ were compared between these groups.

The effects of WZC on the Tac blood concentrations (CO, CO/D, and CO/D/W) were further assessed in LT patients who received WZC on the 14th day but not on the 7th day after surgery. As shown in the upper panels in Fig. 1, the CO, CO/D, and Co/D/W were $8.000 \mathrm{ng} / \mathrm{ml}, 1.333 \mathrm{ng} / \mathrm{ml}$ per $\mathrm{mg}$, and $94.900 \mathrm{ng} / \mathrm{ml} \mathrm{per} \mathrm{mg/kg}$ on the 14 th day, significantly higher than the corresponding values of $5.000 \mathrm{ng} / \mathrm{ml}(P<0.001), 0.983 \mathrm{ng} / \mathrm{ml}$ per $\mathrm{mg}(P<0.001)$, and $66.867 \mathrm{ng} / \mathrm{ml} \mathrm{per} \mathrm{mg} / \mathrm{kg}(P<0.001)$ on the 7th day. It was noteworthy that a higher dose of WZC led to increased effects on the CO, CO/D, and CO/D/W, which were $10.600 \mathrm{ng} / \mathrm{ml}, 1.830 \mathrm{ng} / \mathrm{ml}$ per $\mathrm{mg}$, and $123.817 \mathrm{ng} / \mathrm{ml} \mathrm{per} \mathrm{mg/kg} \mathrm{in} \mathrm{patients} \mathrm{who} \mathrm{received} \mathrm{a} \mathrm{higher} \mathrm{dose} \mathrm{of} \mathrm{WZC} \mathrm{on} \mathrm{the} \mathrm{14th}$ day. The corresponding values were $6.600 \mathrm{ng} / \mathrm{ml}(P=0.034), 1.214 \mathrm{ng} / \mathrm{ml}$ per $\mathrm{mg}(P=0.004)$, and $78.524 \mathrm{ng} / \mathrm{ml} \mathrm{per} \mathrm{mg} / \mathrm{kg}(P$ $=0.004$ ) on the 7th day after LT (lower panels, Fig. 1). These data provided direct evidence that WZC significantly elevated the Tac blood concentrations in LT patients.

\section{Discussion}

This study assessed the effects of the traditional Chinese medicine WZC on Tac blood concentrations in 185 LT patients with different combinations of donor-recipient CYP3A5 genotypes. The major novel findings were as follows: (1) Donor-recipient CYP3A5 genotypes significantly affected the Tac blood concentrations, with the lowest CO, CO/D, and C0/D/W observed in the $\mathrm{R}+/ \mathrm{D}+$ group on days 7 and 14 after LT; (2) Tac blood levels were significantly elevated by the use of WZC in LT patients in the $\mathrm{R}+/ \mathrm{D}+, \mathrm{R}+/ \mathrm{D}-$-, and R-/D + groups; (3) Greater increases in the CO/D and C0/D/W were significantly associated with higher doses of WZC; (4) The use of WZC reduced the need for Tac dose adjustment, especially in the R+/D+, R+/D-, and R-/D + groups.

Tac is a powerful immunosuppressant that is widely used for patients who undergo solid organ transplantation (8). However, the narrow therapeutic window of Tac presents a clinical challenge. For instance, too low a dose can lead to rejection, and too high a dose can cause drug-induced toxicity (15). Therefore, the target $C 0$ is generally set at $5-10 \mathrm{ng} / \mathrm{ml}(16)$ and the oral dose of Tac is adjusted according to the blood concentration. Tac is mainly metabolized by CYP3A4 and CYP3A5 in the liver and small intestine, while P glycoprotein, a product of the multidrug resistance 1 gene (MDR1) or the so called ATP-binding cassette $(A B C)$ transporter, $A B C B 1$, limits the absorption of Tac by pumping it out of the cell $(16,17)$. Due to the low frequency of polymorphisms, it is difficult to attribute large pharmacokinetic changes to the CYP3A4 genotype alone (18), and no significant difference between the high- and low-CYP3A4 groups in Tac dosage or the C/D ratio has been reported (16). Although intra-individual variations in the C0/D ratio are closely related to the expression level of MDR1, there is no significant relationship between the C3435T single nucleotide polymorphism (SNP) in the MDR1 gene and the pharmacokinetics of Tac (16) and the impact of the SNP is rather limited $(19,20)$.

Previous studies have demonstrated that the variations of the CYP3A5 genotypes largely contribute to Tac disposition (2022). The SNP in intron 3 of the CYP3A5 gene (CYP3A5*3, g.6986A > G, rs776746) can cause splicing errors and abnormal 
splicing of mRNA to stop codons prematurely, thereby deactivating enzymes (1). Many previous studies have reported the significant impact of CYP3A5*3 SNPs on the pharmacokinetics of Tac, causing the enzyme to lose its activity $(16,23,24)$. In CYP3A5 expressers, the weight-corrected Tac daily dose requirements and weight-corrected steady-state clearance were $\sim 1.8$ fold higher, while the dose-corrected $\mathrm{CO}$ and AUCO-12 were 2.0-fold lower than those of CYP3A5 non-expressers (25). Intestinal CYP3A5 and hepatic CYP3A5 play important roles in the oral clearance of Tac (16). In this study, according to the donor-recipient CYP3A5 genotypes, the185 LT recipients were divided into four groups: R+/D + group, R+/D- group, R-/D + group, R-/D- group. The different combinations represented the intestinal and hepatic CYP3A5 activity. We found that the CO/D and C0/D/W in the R+/D + group were the lowest among the groups on the 7th day, while the CO/D and CO/D/W of the R-/Dgroup were significantly higher than those of the other three groups on the 14th day. These findings are consistent with previous studies $(16,24)$, indicating that either the intestinal enzyme activity or the liver enzyme activity improved on day 14 after LT. Unlike the intestinal CYP3A5 enzyme, which is responsible for stronger Tac metabolism than the liver CYP3A5 enzyme in the early stages after LDLT as reported previously $(11,26)$, this study has shown that the C0, CO/D, and C0/D/W of the R+/Dand R-/D + groups are not significantly different on days 7 and 14 after LT. This indicates that the CYP3A5 enzymes in the intestine and liver have no significant differences in Tac metabolism in the early stages after LT.

WZC is a traditional Chinese medicine extracted from Schisandra sphenanthera and is widely used to treat liver damage caused by hepatoxins, viral hepatitis, or acetaminophen $(9,10,27)$. Its active ingredients are schisandrins $(A, B, C)$, schisandrols (A, B), and schisantherins (A, B) (28). Qin et al reported that the lignans in WZC and Tac were both substrates of CYP3A, the affinity of the WZC lignans to CYP3A was much higher than that of Tac, and WZCs successfully competed against Tac with a much stronger metabolism (29). Studies in rats and healthy volunteers have demonstrated that the active ingredients of WZC may increase the oral bioavailability of Tac and maintain its blood concentration by inhibiting the metabolism of CYP3A-mediated Tac and the P glycoprotein-mediated efflux of Tac $(11,14)$. Co-administration of Wuzhi tablet significantly reduced the Tac dose requirements without impairing its immunosuppressive effect (30). In the present study, we explored the potentially beneficial effects of WZC in patients with different donor-recipient CYP3A5 genotypes. On day 7 after $\mathrm{LT}$, the $\mathrm{CO} / \mathrm{D}$ and $\mathrm{CO} / \mathrm{D} / \mathrm{W}$ in the $\mathrm{R}+/ \mathrm{D}+$ group were significantly lower than the values in the other three groups. On day 14 , the $\mathrm{CO} / \mathrm{D}$ and $\mathrm{CO} / \mathrm{D} / \mathrm{W}$ of the R-/D- group was significantly higher than those of the other three groups. It may merit attention that the use of WZC diminished the difference in Tac metabolism caused by variations in the CYP3A5 genotypes, thereby reducing the required dose of Tac in the enzyme expression groups (R+/D+, R+/D-, and R-/D + groups).

Qin and colleagues reported that the AUC value after oral Tac dosing increased by 2.1 fold and that the oral bioavailability (Foral) of Tac increased from 5.4-13.2\% when co-administered with WZC (11). In this study, we observed that WZC significantly increased the $C 0, C 0 / D$, and $C 0 / D / W$ on day 14 compared with the values on day 7 . It can be concluded that WZC can significantly increase the blood concentration of Tac and has a superimposing effect; that is, increasing the dose of WZC can further increase the blood concentration of Tac.

\section{Conclusion}

the present study has demonstrated that the donor-recipient CYP3A5 genotypes significantly affect the blood concentrations of Tac in patients after LT. Notably, WZC significantly increased the C0, C0/D, and C0/D/W in the CYP3A5 expression groups ( R+/D+, R+/D-, and R-/D + groups) through inhibiting the CYP3A5 enzymatic activity. As such, WZC holds promise to abrogate the unfavorable effects of the donor-recipient CYP3A5 genotypes on the Tac dose requirements in patients after LT.

\section{Abbreviations}

ALT, alanine transferase; AST, aspartate transferase; AUC, area under the concentration-time curve; $\mathrm{C} 0$, trough concentration of tacrolimus; C0/D, dose-adjusted trough concentration of tacrolimus; $\mathrm{CO} / \mathrm{D} / \mathrm{W}$, dose- and body weight-adjusted trough concentration of tacrolimus; CYP3A, cytochrome P450 enzyme 3A; LT, liver transplantation; SNP, single nucleotide polymorphism; Tac, tacrolimus; WZC, Wuzhi capsule 


\section{Declarations}

\section{Ethics approval and consent to participate}

No organs from executed prisoners were used in our study. The study protocal was approved by the ethical committee of Bethune Hospital 1, China. Written consent for publication of the article was obtained.

\section{Consent to publish}

All authors approved the final version for publication.

\section{Availability of data and materials}

We are committed to the reliability of the data used

\section{Competing interests}

All authors declare there were no conflict of interests involved.

\section{Funding}

This work was Supported by the Projects of Department of Science and Technology of Jilin Province, No.20180622004JC

\section{Authors' Contributions}

Guoyue Lv and Kai Kou contributed to the study design.

Xiaodong Sun, Mingqian Li, Ting Li and Yuelei Hu contributed significantly to manuscript preparation, including collection, analysis, and interpretation of data;

Kai Kou and Shuxuan Li wrote the manuscript;

\section{Acknowledgements}

Thanks to all the participants.

\section{References}

1. Hustert E, Haberl M, Burk O, Wolbold R, He YQ, Klein K, Nuessler AC, et al. The genetic determinants of the CYP3A5 polymorphism. Pharmacogenetics 2001;11:773-779.

2. Gijsen VMGJ, Madadi P, Dube MP, Hesselink DA, Koren G, de Wildt SN. Tacrolimus-induced nephrotoxicity and genetic variability: A review. Annals of Transplantation 2012;17:111-121.

3. Taniai N, Akimaru K, Ishikawa Y, Kanada T, Kakinuma D, Mizuguchi Y, Mamada Y, et al. Hepatotoxicity caused by both tacrolimus and cyclosporine after living donor liver transplantation. J Nippon Med Sch 2008;75:187-191.

4. Maluccio M, Sharma V, Lagman M, Vyas S, Yang H, Li BG, Suthanthiran M. Tacrolimus enhances transforming growth factor-beta(1) expression and promotes tumor progression. Transplantation 2003;76:597-602.

5. Hernandez-Fisac I, Pizarro-Delgado J, Calle C, Marques M, Sanchez A, Barrientos A, Tamarit-Rodriguez J. Tacrolimusinduced diabetes in rats courses with suppressed insulin gene expression in pancreatic islets. American Journal of Transplantation 2007;7:2455-2462.

6. Yan L, Yang ZQ, Shi YY, Ren L, Yang CL, Wan ZL, Bai YJ, et al. Effects of Wuzhi Capsules on Blood Concentration of Tacrolimus in Renal Transplant Recipients. Annals of Transplantation 2019;24:594-604. 
7. Bowman LJ, Brennan DC. The role of tacrolimus in renal transplantation. Expert Opinion on Pharmacotherapy 2008;9:635643.

8. Staatz CE, Tett SE. Clinical pharmacokinetics and pharmacodynamics of tacrolimus in solid organ transplantation. Clinical Pharmacokinetics 2004;43:623-653.

9. Xie YA, Hao HP, Kang A, Liang Y, Xie T, Sun SQ, Dai C, et al. Integral pharmacokinetics of multiple lignan components in normal, CCl4-induced hepatic injury and hepatoprotective agents pretreated rats and correlations with hepatic injury biomarkers. Journal of Ethnopharmacology 2010;131:290-299.

10. Loo WTY, Cheung MNB, Chow LWC. Fructus schisandrae (Wuweizi)-containing compound inhibits secretion of HBsAg and HBeAg in hepatocellular carcinoma cell line. Biomedicine \& Pharmacotherapy 2007;61:606-610.

11. Qin XL, Bi HC, Wang XD, Li JL, Wang Y, Xue XP, Chen X, et al. Mechanistic understanding of the different effects of Wuzhi Tablet (Schisandra sphenanthera extract) on the absorption and first-pass intestinal and hepatic metabolism of Tacrolimus (FK506). International Journal of Pharmaceutics 2010;389:114-121.

12. Kawasaki S, Makuuchi M, Ishizone S, Matsunami H, Terada M, Kawarazaki H. Liver regeneration in recipients and donors after transplantation. Lancet 1992;339:580-581.

13. Jusko WJ, Piekoszewski W, Klintmalm GB, Shaefer MS, Hebert MF, Piergies AA, Lee CC, et al. Pharmacokinetics of tacrolimus in liver transplant patients. Clin Pharmacol Ther 1995;57:281-290.

14. Qin XL, Yu T, Li LJ, Wang Y, Gu HM, Wang YT, Huang M, et al. Effect of long-term co-administration of Wuzhi tablet (Schisandra sphenanthera extract) and prednisone on the pharmacokinetics of tacrolimus. Phytomedicine 2013;20:375379.

15. Ferjani H, El Arem A, Bouraoui A, Achour A, Abid S, Bacha H, Boussema-Ayed I. Protective effect of mycophenolate mofetil against nephrotoxicity and hepatotoxicity induced by tacrolimus in Wistar rats. Journal of Physiology and Biochemistry 2016;72:133-144.

16. Masuda S, Inui K. An up-date review on individualized dosage adjustment of calcineurin inhibitors in organ transplant patients. Pharmacology \& Therapeutics 2006;112:184-198.

17. Yan L, Li Y, Tang JT, An YF, Wang LL, Shi YY. Donor ABCB1 3435 C > T genetic polymorphisms influence early renal function in kidney transplant recipients treated with tacrolimus. Pharmacogenomics 2016;17:249-257.

18. Chowbay B, Zhou SF, Lee EJD. An interethnic comparison of polymorphisms of the genes encoding drug-metabolizing enzymes and drug transporters: Experience in Singapore. Drug Metabolism Reviews 2005;37:327-378.

19. de Jonge H, Kuypers DR. Pharmacogenetics in solid organ transplantation: current status and future directions. Transplant Rev (Orlando) 2008;22:6-20.

20. Jacobson PA, Oetting WS, Brearley AM, Leduc R, Guan W, Schladt D, Matas AJ, et al. Novel polymorphisms associated with tacrolimus trough concentrations: results from a multicenter kidney transplant consortium. Transplantation 2011;91:300-308.

21. Macphee IA, Fredericks S, Tai T, Syrris P, Carter ND, Johnston A, Goldberg L, et al. Tacrolimus pharmacogenetics: polymorphisms associated with expression of cytochrome p4503A5 and P-glycoprotein correlate with dose requirement. Transplantation 2002;74:1486-1489.

22. Hesselink DA, van Schaik RH, van der Heiden IP, van der Werf M, Gregoor PJ, Lindemans J, Weimar W, et al. Genetic polymorphisms of the CYP3A4, CYP3A5, and MDR-1 genes and pharmacokinetics of the calcineurin inhibitors cyclosporine and tacrolimus. Clin Pharmacol Ther 2003;74:245-254.

23. Kurzawski M, Drozdzik M. Pharmacogenetics in solid organ transplantation: genes involved in mechanism of action and pharmacokinetics of immunosuppressive drugs. Pharmacogenomics 2013;14:1099-1118.

24. Uesugi M, Masuda S, Katsura T, Oike F, Takada Y, Inui K. Effect of intestinal CYP3A5 on postoperative tacrolimus trough levels in living-donor liver transplant recipients. Pharmacogenet Genomics 2006;16:119-127.

25. de Jonge $\mathrm{H}$, de Loor H, Verbeke $\mathrm{K}$, Vanrenterghem $\mathrm{Y}$, Kuypers DR. In vivo CYP3A4 activity, CYP3A5 genotype, and hematocrit predict tacrolimus dose requirements and clearance in renal transplant patients. Clin Pharmacol Ther 
2012;92:366-375.

26. Undre NA, Stevenson P, Schafer A. Pharmacokinetics of tacrolimus: clinically relevant aspects. Transplant Proc 1999;31:21S-24S.

27. Fan XM, Chen P, Jiang YM, Wang Y, Tan HS, Zeng H, Wang YT, et al. Therapeutic Efficacy of Wuzhi Tablet (Schisandra sphenanthera Extract) on Acetaminophen-Induced Hepatotoxicity through a Mechanism Distinct from N-Acetylcysteine. Drug Metabolism and Disposition 2015;43:317-324.

28. Huyke C, Engel K, Simon-Haarhaus B, Quirin KW, Schempp CM. Composition and biological activity of different extracts from Schisandra sphenanthera and Schisandra chinensis. Planta Medica 2007;73:1116-1126.

29. Qin XL, Chen X, Zhong GP, Fan XM, Wang Y, Xue XP, Wang Y, et al. Effect of Tacrolimus on the pharmacokinetics of bioactive lignans of Wuzhi tablet (Schisandra sphenanthera extract) and the potential roles of CYP3A and P-gp.

Phytomedicine 2014;21:766-772.

30. Li JL, Chen SY, Qin XL, Fu Q, Bi HC, Zhang Y, Wang XD, et al. Wuzhi Tablet (Schisandra sphenanthera Extract) is a Promising Tacrolimus-Sparing Agent for Renal Transplant Recipients Who are CYP3A5 Expressers: a Two-Phase Prospective Study. Drug Metabolism and Disposition 2017;45:1114-1119.

\section{Tables}

Table 1 Baseline characteristics of the enrolled liver transplant patients

\begin{tabular}{|c|c|c|c|c|c|c|}
\hline \multirow[t]{2}{*}{ Characteristics } & & \multicolumn{4}{|c|}{ Patients with different combinations of recipient-donor CYP3A5 genotypes } & \multirow[t]{2}{*}{$\overline{\mathrm{P}}$} \\
\hline & & $\begin{array}{l}\mathrm{R}+/ \mathrm{D}+ \\
(\mathrm{n}=47)\end{array}$ & $\begin{array}{l}\mathrm{R}+/ \mathrm{D}- \\
(\mathrm{n}=48)\end{array}$ & $\begin{array}{l}\mathrm{R}-/ \mathrm{D}+ \\
(\mathrm{n}=45)\end{array}$ & $\begin{array}{l}\text { R-/D- } \\
(n=45)\end{array}$ & \\
\hline Age (years) & & $53.130 \pm 11.056$ & $53.350 \pm 10.457$ & $52.910 \pm 9.202$ & $51.870 \pm 9.341$ & 0.899 \\
\hline \multirow[t]{2}{*}{ Gender } & Male & 31 & 36 & 35 & 36 & \multirow[t]{2}{*}{0.425} \\
\hline & Femal & 216 & 12 & 10 & 9 & \\
\hline \multirow[t]{4}{*}{ Blood type } & A & 17 & 10 & 14 & 14 & \multirow[t]{4}{*}{0.759} \\
\hline & B & 12 & 17 & 16 & 13 & \\
\hline & $\mathrm{AB}$ & 5 & 4 & 4 & 7 & \\
\hline & $\mathrm{O}$ & 13 & 17 & 11 & 11 & \\
\hline $\begin{array}{l}\text { Body weight }(\mathrm{kg}) \text { on } \\
\text { day } 7\end{array}$ & & $67.709 \pm 14.114$ & $65.802 \pm 14.961$ & $69.567 \pm 11.568$ & $66.700 \pm 10.537$ & 0.545 \\
\hline AST $(u / L)$ on day 7 & & $\begin{array}{l}31.000(20.500- \\
59.000)\end{array}$ & $\begin{array}{l}33.900(21.100- \\
62.325)\end{array}$ & $\begin{array}{l}31.100(21.750- \\
53.050)\end{array}$ & $\begin{array}{l}28.800(20.250- \\
60.350)\end{array}$ & 0.991 \\
\hline $\operatorname{ALT}(\mathrm{u} / \mathrm{L})$ on day 7 & & $\begin{array}{l}83.200(48.100- \\
187.100)\end{array}$ & $\begin{array}{l}92.550(56.925- \\
147.875)\end{array}$ & $\begin{array}{l}86.500(59.500- \\
144.200)\end{array}$ & $\begin{array}{l}102.900(54.250- \\
157.650)\end{array}$ & 0.963 \\
\hline $\begin{array}{l}\text { Albumin (g/L) on day } \\
7\end{array}$ & & $\begin{array}{l}37.400(34.100- \\
40.300)\end{array}$ & $\begin{array}{l}38.100(34.325- \\
42.000)\end{array}$ & $\begin{array}{l}37.600(35.450- \\
41.350)\end{array}$ & $\begin{array}{l}39.600(35.600- \\
42.500)\end{array}$ & 0.491 \\
\hline $\begin{array}{l}\text { Hemoglobin } \mathrm{b} \\
(\mathrm{g} / \mathrm{L}) \text { on day } 7\end{array}$ & & $\begin{array}{l}101.000(90.000- \\
112.000)\end{array}$ & $\begin{array}{l}107.500(95.500- \\
116.750)\end{array}$ & $\begin{array}{l}103.000(98.000- \\
116.500)\end{array}$ & $\begin{array}{l}103.000(89.000- \\
110.000)\end{array}$ & 0.169 \\
\hline $\begin{array}{l}\text { Bilirubin (umol/L) on } \\
\text { day } 7\end{array}$ & & $\begin{array}{l}30.900(20.200- \\
52.100)\end{array}$ & $\begin{array}{l}36.200(21.450- \\
66.600)\end{array}$ & $\begin{array}{l}30.200(19.500- \\
45.200)\end{array}$ & $\begin{array}{l}25.100(17.600- \\
64.050)\end{array}$ & 0.415 \\
\hline $\begin{array}{l}\text { Creatinine (umol/L) } \\
\text { on day } 7\end{array}$ & & $\begin{array}{l}55.300(45.400- \\
66.100)\end{array}$ & $\begin{array}{l}51.900(45.425- \\
66.300)\end{array}$ & $\begin{array}{l}55.100(44.450- \\
67.950)\end{array}$ & $\begin{array}{l}56.800(47.900- \\
64.550)\end{array}$ & 0.732 \\
\hline $\begin{array}{l}\text { Body weight }(\mathrm{kg}) \text { on } \\
\text { day } 14\end{array}$ & & $67.936 \pm 14.060$ & $65.917 \pm 14.850$ & $69.718 \pm 11.492$ & $66.878 \pm 10.391$ & 0.531 \\
\hline AST $(\mathrm{u} / \mathrm{L})$ on day 14 & & $\begin{array}{l}23.500(17.800- \\
38.400)\end{array}$ & $\begin{array}{l}21.500(15.550- \\
34.400)\end{array}$ & $\begin{array}{l}21.500(17.550- \\
32.250)\end{array}$ & $\begin{array}{l}23.900(15.900- \\
31.950)\end{array}$ & 0.935 \\
\hline $\operatorname{ALT}(\mathrm{u} / \mathrm{L})$ on day 14 & & $\begin{array}{l}48.400(23.100- \\
85.400)\end{array}$ & $\begin{array}{l}43.150(22.200- \\
69.775)\end{array}$ & $\begin{array}{l}41.900(27.500- \\
99.000)\end{array}$ & $\begin{array}{l}52.800(21.650- \\
94.700)\end{array}$ & 0.861 \\
\hline $\begin{array}{l}\text { Albumin }(g / L) \text { on day } \\
14\end{array}$ & & $\begin{array}{l}39.400(36.400- \\
43.900)\end{array}$ & $\begin{array}{l}38.550(35.700- \\
42.650)\end{array}$ & $\begin{array}{l}38.200(35.550- \\
42.150)\end{array}$ & $\begin{array}{l}38.200(33.850- \\
42.550)\end{array}$ & 0.451 \\
\hline $\begin{array}{l}\text { Hemoglobin }(\mathrm{g} / \mathrm{L}) \text { on } \\
\text { day } 14\end{array}$ & & $\begin{array}{l}102.000(92.000- \\
111.000)\end{array}$ & $\begin{array}{l}101.000(92.000- \\
112.000)\end{array}$ & $\begin{array}{l}105.00(93.500- \\
114.000)\end{array}$ & $\begin{array}{l}103.000(90.000- \\
112.500)\end{array}$ & 0.879 \\
\hline $\begin{array}{l}\text { Bilirubin (umol/L) on } \\
\text { day } 14\end{array}$ & & $\begin{array}{l}23.100(14.700- \\
33.600)\end{array}$ & $\begin{array}{l}24.100(15.675- \\
38.400)\end{array}$ & $\begin{array}{l}20.400(14.750- \\
27.850)\end{array}$ & $\begin{array}{l}22.500(13.800- \\
40.600)\end{array}$ & 0.464 \\
\hline $\begin{array}{l}\text { Creatinine (umol/L) } \\
\text { on day } 14\end{array}$ & & $\begin{array}{l}56.600(48.900- \\
78.200)\end{array}$ & $\begin{array}{l}60.850(47.250- \\
73.175)\end{array}$ & $\begin{array}{l}58.900(46.900- \\
71.200)\end{array}$ & $\begin{array}{l}57.700(48.550- \\
73.600)\end{array}$ & 0.983 \\
\hline
\end{tabular}


Note: R, recipient; D, donor; ALT, alanine transferase; AST, aspartate transferase. Normally distributed data are expressed as mean \pm standard deviation $(\mathrm{x} \pm \mathrm{s})$; Non-normally distributed data are presented as median and quartile M (Q1-Q3).

Table 2 Tac blood concentrations in patients with different recipient-donor CYP3A5 genotypes

\begin{tabular}{|c|c|c|c|c|c|c|c|c|c|}
\hline $\begin{array}{l}\text { Tac } \\
\text { concentrations } \\
\text { C0 }(\mathrm{ng} / \mathrm{ml})\end{array}$ & \multicolumn{2}{|c|}{$\begin{array}{l}\mathrm{R}+/ \mathrm{D}+\text { group } \\
(\mathrm{n}=47)\end{array}$} & \multicolumn{2}{|c|}{$\begin{array}{l}\mathrm{R}+/ \mathrm{D}-\text { group } \\
(\mathrm{n}=48)\end{array}$} & \multicolumn{2}{|c|}{$\begin{array}{l}\mathrm{R}-/ \mathrm{D}+\text { group } \\
(\mathrm{n}=45)\end{array}$} & \multicolumn{2}{|c|}{$\begin{array}{l}\text { R-/D- group } \\
(\mathrm{n}=45)\end{array}$} & P-value \\
\hline 7th day & $\begin{array}{l}5.600 \\
6.800)\end{array}$ & (4.100- & $\begin{array}{l}7.350 \\
9.300)\end{array}$ & (5.625- & $\begin{array}{l}6.200 \\
8.150)\end{array}$ & (4.900- & $\begin{array}{l}7.900 \\
10.200)\end{array}$ & (5.600- & $<0.001^{* *}$ \\
\hline 14th day & $\begin{array}{l}7.100 \\
9.300)\end{array}$ & (5.600- & $\begin{array}{l}8.550 \\
11.175)\end{array}$ & (6.425- & $\begin{array}{l}7.700 \\
10.450)\end{array}$ & (5.600- & $\begin{array}{l}9.300 \\
11.300)\end{array}$ & (8.100- & $0.008^{* *}$ \\
\hline $\begin{array}{l}\mathrm{C} 0 / \mathrm{D} \\
(\mathrm{ng} / \mathrm{ml} \\
\mathrm{mg})\end{array}$ & & & & & & & & & \\
\hline 7th day & $\begin{array}{l}1.000 \\
1.233)\end{array}$ & (0.717- & $\begin{array}{l}1.379 \\
1.619)\end{array}$ & (1.123- & $\begin{array}{l}1.350 \\
1.767)\end{array}$ & (0.973- & $\begin{array}{l}1.740 \\
2.245)\end{array}$ & (1.239- & $<0.001 * *$ \\
\hline 14th day & $\begin{array}{l}1.180 \\
1.500)\end{array}$ & (0.886- & $\begin{array}{l}1.410 \\
1.941)\end{array}$ & (1.106- & $\begin{array}{l}1.267 \\
1.925)\end{array}$ & (1.034- & $\begin{array}{l}1.940 \\
2.368)\end{array}$ & (1.588- & $<0.001^{* *}$ \\
\hline $\begin{array}{l}\mathrm{C} 0 / \mathrm{D} / \mathrm{W} \\
(\mathrm{ng} / \mathrm{ml} \\
\mathrm{mg} / \mathrm{kg})\end{array}$ & & & & & & & & & \\
\hline 7th day & $\begin{array}{l}63.600 \\
91.500)\end{array}$ & (42.000- & $\begin{array}{l}90.233 \\
119.881)\end{array}$ & (68.875- & $\begin{array}{l}88.200 \\
127.033)\end{array}$ & (62.545- & $\begin{array}{l}113.600 \\
144.100)\end{array}$ & (86.763- & $<0.001^{* * *}$ \\
\hline 14th day & $\begin{array}{l}79.200 \\
108.233)\end{array}$ & (52.500- & $\begin{array}{l}90.122 \\
124.832)\end{array}$ & (70.333- & $\begin{array}{l}93.917 \\
133.220)\end{array}$ & (54.738- & $\begin{array}{l}129.000 \\
171.594)\end{array}$ & (93.638- & $<0.001 * *$ \\
\hline
\end{tabular}

Note: C0, trough concentration of tacrolimus; C0/D, dose-adjusted trough concentration of tacrolimus; $\mathrm{C} 0 / \mathrm{D} / \mathrm{W}$, dose- and body weight-adjusted trough concentration of tacrolimus. Data are expressed as median and quartile $\mathrm{M}(\mathrm{Q} 1-\mathrm{Q} 3) ; * \mathrm{P}<0.05 ; * * \mathrm{P}<0.01$.

Table 3 Pairwise comparison between groups

\begin{tabular}{llllllll}
\hline Tac concentrations & & $\mathrm{P} 1$ & $\mathrm{P} 2$ & $\mathrm{P} 3$ & $\mathrm{P} 4$ & $\mathrm{P} 5$ & $\mathrm{P} 6$ \\
\hline $\mathrm{C} 0$ & 7th day & $\mathbf{0 . 0 0 2 * *}$ & 0.426 & $<0.001^{* *}$ & 0.533 & 1.000 & 0.101 \\
& 14th day & 0.489 & 1.000 & $0.005^{* *}$ & 1.000 & 0.602 & 0.127 \\
C0/D & 7th day & $<0.001^{* *}$ & $0.002^{* *}$ & $<0.001^{* *}$ & 1.000 & 0.137 & 0.076 \\
& 14th day & 0.063 & 0.396 & $<0.001^{* *}$ & 1.000 & $0.003^{* *}$ & $<0.001^{* *}$ \\
C0/D/W & 7th day & $\mathbf{0 . 0 0 6 * *}$ & $0.003^{* *}$ & $<0.001^{* *}$ & 1.000 & 0.166 & 0.302 \\
& 14th day & 0.399 & 0.335 & $<0.001^{* *}$ & 1.000 & $0.007^{* *}$ & $\mathbf{0 . 0 1 2 *}$ \\
\hline
\end{tabular}

Note: C0, trough concentration of tacrolimus; $\mathrm{C} 0 / \mathrm{D}$, dose-adjusted trough concentration of tacrolimus; $\mathrm{C} 0 / \mathrm{D} / \mathrm{W}$, dose- and body weight-adjusted trough concentration of tacrolimus. $\mathrm{P} 1: \mathrm{R}+/ \mathrm{D}+\mathrm{vs}$. R+/D-; P2: R+/D+ vs. R-/D+; P3: R+/D+ vs. R-/D-; P4: R+/D- vs. R-/D+; P5: R+/D- vs. R-/D-; P6: R-/D+ vs. R-/D-. * $\mathrm{P}<0.05$ and $* * \mathrm{P}<0.01$.

Table 4 Effects of WZC on Tac blood concentrations in patients with different recipient-donor CYP3A5 genotypes 


\begin{tabular}{|c|c|c|c|c|c|c|c|}
\hline $\begin{array}{l}\text { Tac } \\
\text { concentrations }\end{array}$ & & & $\overline{\mathrm{R}+/ \mathrm{D}+}$ & $\mathrm{R}+/ \mathrm{D}-$ & $\mathrm{R}-/ \mathrm{D}+$ & R-/D- & P-value \\
\hline \multirow{5}{*}{$\begin{array}{l}\mathrm{C} 0 \\
(\mathrm{ng} / \mathrm{ml})\end{array}$} & 7th & Non-WZCs & $5.300(4.100-$ & 7.000 (5.400- & $5.600(4.400-$ & $7.800(5.400-$ & $<0.001 * *$ \\
\hline & & WZCs (32) & $\begin{array}{l}0.525) \\
7.000(3.950-\end{array}$ & $\begin{array}{l}0.950) \\
11.000\end{array}$ & $9.500(5.780-$ & $8.550(6.100-$ & 0.212 \\
\hline & 14th & Non-WZCs & $6.200(4.300-$ & 8.050 (5.725- & $6.800(5.250-$ & 9.100 (7.900- & $0.004 * * *$ \\
\hline & day & (112) & $8.700)$ & $10.500)$ & $9.075)$ & 11.300) & \\
\hline & & WZCs (73) & $\begin{array}{l}7.300(6.475- \\
10.375)\end{array}$ & $\begin{array}{l}8.850(6.975- \\
13.375)\end{array}$ & $\begin{array}{l}9.600(7.600- \\
11.900)\end{array}$ & $\begin{array}{l}10.700(8.550- \\
16.000)\end{array}$ & 0.166 \\
\hline \multirow{5}{*}{$\begin{array}{l}\text { C0/D } \\
\text { (ng/ml per } \\
\text { mg) }\end{array}$} & $\begin{array}{l}\text { 7th } \\
\text { day }\end{array}$ & $\begin{array}{l}\text { Non-WZCs } \\
\text { (153) }\end{array}$ & $\begin{array}{l}0.993(0.713- \\
1.155)\end{array}$ & $\begin{array}{l}1.333(1.066- \\
1.578)\end{array}$ & $\begin{array}{l}1.350(0.975- \\
1.700)\end{array}$ & $\begin{array}{l}1.740(1.175- \\
2.400)\end{array}$ & $<0.001 * *$ \\
\hline & & WZCs (32) & 1.167 (0.796- & 1.571 (1.267- & $0.941-$ & 529- & 0.138 \\
\hline & & & 1.533) & 1.957) & $2.113)$ & $2.160)$ & \\
\hline & $\begin{array}{l}\text { 14th } \\
\text { day }\end{array}$ & $\begin{array}{l}\text { Non-WZCs } \\
\text { (112) }\end{array}$ & $\begin{array}{l}1.025(0.833- \\
1.400)\end{array}$ & $\begin{array}{l}1.400(1.078- \\
1.880)\end{array}$ & $\begin{array}{l}1.185(0.893- \\
1.549)\end{array}$ & $\begin{array}{l}1.940 \\
2.275)\end{array}$ & $<0.001 * *$ \\
\hline & & WZCs (73) & $\begin{array}{l}1.321(1.010- \\
1.763)\end{array}$ & $\begin{array}{l}1.533(1.192- \\
2.079)\end{array}$ & $\begin{array}{l}1.633(1.194- \\
2.117)\end{array}$ & $\begin{array}{l}1.912(1.657- \\
2.513)\end{array}$ & $0.020 *$ \\
\hline \multirow[t]{4}{*}{$\begin{array}{l}\text { CO/D/W } \\
\text { (ng/ml per } \\
\mathrm{mg} / \mathrm{kg})\end{array}$} & $\begin{array}{l}\text { 7th } \\
\text { day }\end{array}$ & $\begin{array}{l}\text { Non-WZCs } \\
\text { (153) }\end{array}$ & $\begin{array}{l}63.575 \\
(42.750- \\
87.188)\end{array}$ & $\begin{array}{l}87.111 \\
(68.717- \\
114.889)\end{array}$ & $\begin{array}{l}87.500 \\
(65.600- \\
118.125)\end{array}$ & $\begin{array}{l}113.600 \\
(85.167- \\
154.000)\end{array}$ & $<0.001 * *$ \\
\hline & & WZCs (32) & $\begin{array}{l}100.000 \\
(40.175- \\
114.167)\end{array}$ & $\begin{array}{l}106.875 \\
(82.333- \\
135.043)\end{array}$ & $\begin{array}{l}114.342 \\
(57.593- \\
177.750)\end{array}$ & $\begin{array}{l}112.876 \\
(95.741- \\
135.488)\end{array}$ & 0.378 \\
\hline & $\begin{array}{l}\text { 14th } \\
\text { day }\end{array}$ & $\begin{array}{l}\text { Non-WZCs } \\
(112)\end{array}$ & $\begin{array}{l}61.600 \\
(45.419 \\
90.750)\end{array}$ & $\begin{array}{l}88.280 \\
(74.786- \\
120.207)\end{array}$ & $\begin{array}{l}77.100 \\
(53.850- \\
104.845)\end{array}$ & $\begin{array}{l}129.000 \\
(90.850- \\
166.875)\end{array}$ & $<0.001 * *$ \\
\hline & & WZCs (73) & $\begin{array}{l}95.536 \\
(59.643- \\
124.913)\end{array}$ & $\begin{array}{l}96.180 \\
(67.550- \\
148.163)\end{array}$ & $\begin{array}{l}107.829 \\
(88.625- \\
142.579)\end{array}$ & $\begin{array}{l}127.408 \\
(100.223- \\
185.128)\end{array}$ & 0.098 \\
\hline
\end{tabular}

Note: C0, trough concentration of tacrolimus; C0/D, dose-adjusted trough concentration of tacrolimus; $\mathrm{C} 0 / \mathrm{D} / \mathrm{W}$, dose- and body weight-adjusted trough concentration of tacrolimus. Data are presented as median and quartile $\mathrm{M}(\mathrm{Q} 1-\mathrm{Q} 3) .{ }^{*} \mathrm{P}<0.05 ; * * \mathrm{P}<0.01$.

Table 5 Pairwise comparison between groups

\begin{tabular}{|c|c|c|c|c|c|c|c|c|}
\hline Tac concentrations & & & P1 & $\overline{\mathrm{P} 2}$ & $\overline{\mathrm{P}}$ & $\mathrm{P} 4$ & $\mathrm{P} 5$ & $\mathrm{P} 6$ \\
\hline \multirow[t]{3}{*}{$\mathrm{CO}$} & 7th day & Non-WZCs & $0.007 * *$ & 1.000 & $<0.001 * *$ & 0.363 & 1.000 & $0.020^{*}$ \\
\hline & 14th day & $\begin{array}{l}\text { WZCs } \\
\text { Non-WZCs }\end{array}$ & 0.457 & $\overline{1} .000$ & $\overline{0.009 * *}$ & $\overline{0}-968$ & 0.870 & $0.029 *$ \\
\hline & & WZCs & & & - & & & \\
\hline \multirow[t]{4}{*}{$\mathrm{C} 0 / \mathrm{D}$} & 7th day & Non-WZCs & $0.002^{* * *}$ & $0.003^{* *}$ & $<0.001^{* * *}$ & 1.000 & 0.169 & 0.210 \\
\hline & & WZCs & & & & & & \\
\hline & 14th day & Non-WZCs & 0.059 & 1.000 & $<0.001 * *$ & 0.923 & $0.021 *$ & $<0.001 * *$ \\
\hline & & WZCs & 1.000 & 0.453 & $0.013 *$ & 1.000 & 0.321 & 0.639 \\
\hline \multirow[t]{4}{*}{$\mathrm{C} 0 / \mathrm{D} / \mathrm{W}$} & 7th day & Non-WZCs & $0.008 * *$ & $0.007 * *$ & $<0.001 * *$ & 1.000 & 0.220 & 0.407 \\
\hline & & WZCs & - & - & - & - & & \\
\hline & 14th day & Non-WZCs & 0.110 & 1.000 & $<0.001 * *$ & 1.000 & $0.036 *$ & $0.002 * *$ \\
\hline & & WZCs & - & - & - & 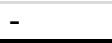 & 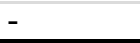 & 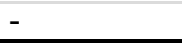 \\
\hline
\end{tabular}

Note: $\mathrm{C} 0$, trough concentration of tacrolimus; $\mathrm{C} 0 / \mathrm{D}$, dose-adjusted trough concentration of tacrolimus; $\mathrm{C} 0 / \mathrm{D} / \mathrm{W}$, dose- and body weight-adjusted trough concentration of tacrolimus. P1: R+/D+ vs. R+/D-; P2: $\mathrm{R}+/ \mathrm{D}+$ vs. R-/D+; P3: R+/D+ vs. R-/D-; P4: R+/D- vs. R-/D+; P5: R+/D- vs. R-/D-; P6: R-/D+ vs. R-/D-. * $\mathrm{P}<0.05$ and $* * \mathrm{P}<0.01$.

Table 6 Self-control grouped according to WZCs 


\begin{tabular}{|c|c|c|c|c|c|c|c|c|c|c|c|c|}
\hline Groups & A (112) & & & B (20) & & & $\mathrm{C}(41)$ & & & $\mathrm{D}(12)$ & & \\
\hline & 7th day & 14th day & P-value & 7th day & 14th day & $\begin{array}{l}\mathrm{P}- \\
\text { value }\end{array}$ & 7th day & 14th day & P-value & 7th day & 14th day & P-value \\
\hline $\mathrm{C} 0$ & $\begin{array}{l}7.000 \\
(5.300- \\
8.875)\end{array}$ & $\begin{array}{l}7.850 \\
(5.650- \\
10.150)\end{array}$ & $0.007 * *$ & $\begin{array}{l}9.950 \\
(7.150- \\
11.750)\end{array}$ & $\begin{array}{l}10.700 \\
(6.600- \\
14.650)\end{array}$ & 0.218 & $\begin{array}{l}5.000 \\
(4.150- \\
6.100)\end{array}$ & $\begin{array}{l}8.000 \\
(6.850- \\
9.750)\end{array}$ & $<0.001 * *$ & $\begin{array}{l}6.600 \\
(5.250- \\
9.200)\end{array}$ & $\begin{array}{l}10.600 \\
(8.875- \\
15.075)\end{array}$ & $0.034^{*}$ \\
\hline $\mathrm{C} 0 / \mathrm{D}$ & $\begin{array}{l}1.427 \\
(1.121- \\
2.013)\end{array}$ & $\begin{array}{l}1.400 \\
(1.025- \\
1.964)\end{array}$ & 0.366 & $\begin{array}{l}1.750 \\
(1.283- \\
2.089)\end{array}$ & $\begin{array}{l}1.729 \\
(1.401- \\
2.442)\end{array}$ & 0.185 & $\begin{array}{l}0.983 \\
(0.808- \\
1.127)\end{array}$ & $\begin{array}{l}1.333 \\
(1.059- \\
1.783)\end{array}$ & $<0.001 * *$ & $\begin{array}{l}1.214 \\
(0.904- \\
1.533)\end{array}$ & $\begin{array}{l}1.830 \\
(1.336- \\
2.470)\end{array}$ & $0.004^{* *}$ \\
\hline $\mathrm{C} 0 / \mathrm{D} / \mathrm{W}$ & $\begin{array}{l}93.670 \\
(68.236- \\
133.333)\end{array}$ & $\begin{array}{l}90.554 \\
(61.848- \\
130.318)\end{array}$ & 0.430 & $\begin{array}{l}112.876 \\
(95.714- \\
134.882)\end{array}$ & $\begin{array}{l}121.304 \\
(89.322- \\
168.515)\end{array}$ & 0.145 & $\begin{array}{l}66.867 \\
(53.077- \\
87.931)\end{array}$ & $\begin{array}{l}94.900 \\
(70.877- \\
124.333)\end{array}$ & $<0.001 * *$ & $\begin{array}{l}78.524 \\
(55.693- \\
114.963)\end{array}$ & $\begin{array}{l}123.817 \\
(84.569- \\
213.863)\end{array}$ & $0.004^{* *}$ \\
\hline
\end{tabular}

Note: A, 112 patients received WZC on the 7th and 14th days after liver transplantation; B, 20 patients were given WZC on both the 7th and 14th days after liver transplantation; C, 41 patients received WZC on the 14th day after liver transplantation only; D, 12 patients received WZC on the $7^{\text {th }}$ day and a higher dose on the 14th day after liver transplantation. $\mathrm{C} 0$, trough concentration of tacrolimus; C0/D, dose-adjusted trough concentration of tacrolimus; $\mathrm{C} 0 / \mathrm{D} / \mathrm{W}$, dose- and body weight-adjusted trough concentration of tacrolimus. Data are expressed as median and quartile $\mathrm{M}(\mathrm{Q} 1-\mathrm{Q} 3) .{ }^{*} \mathrm{P}<0.05,{ }^{* *} \mathrm{P}<0.01$.

\section{Figures}
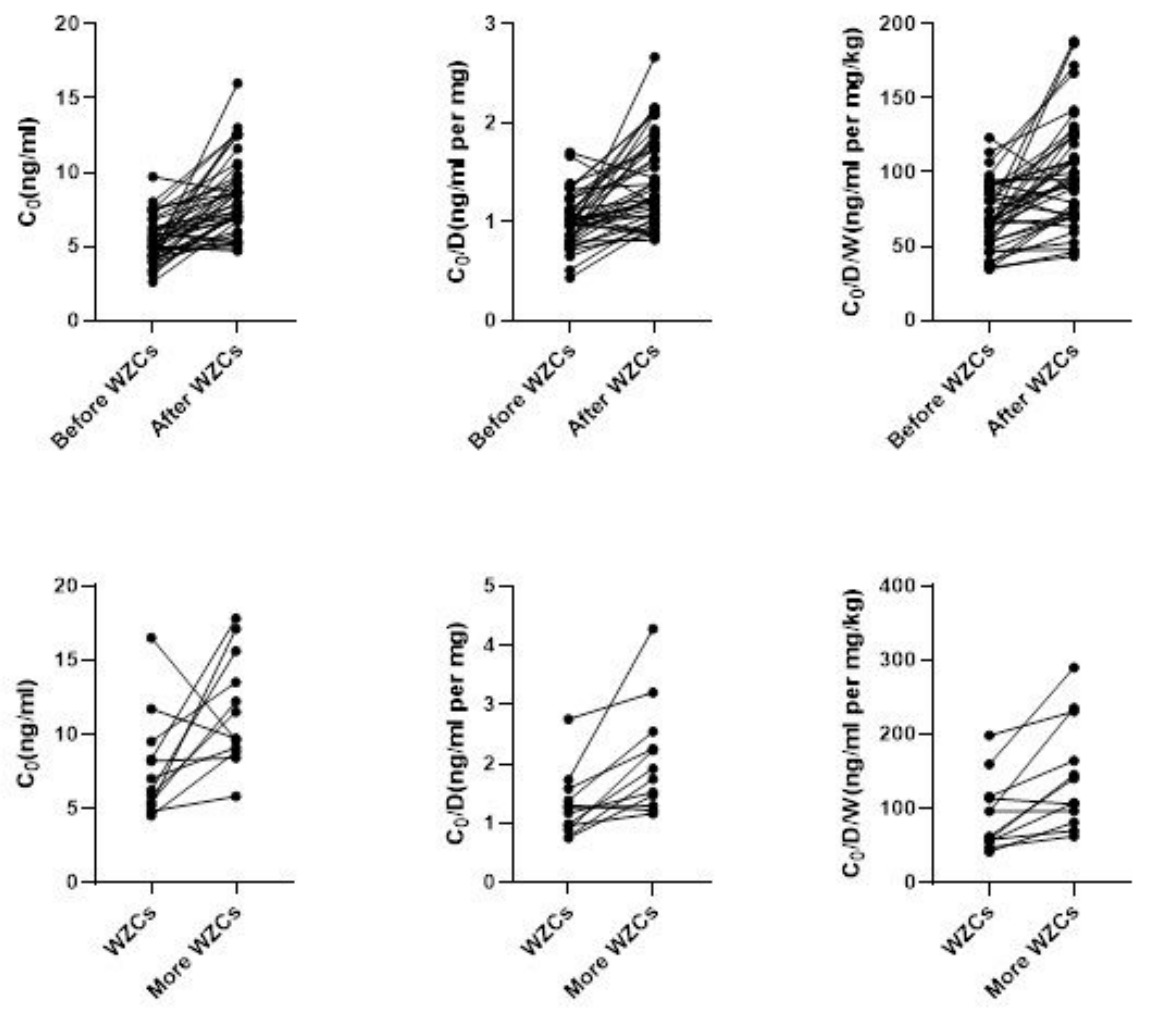

\section{Figure 1}

Effects of WZC on the blood concentrations of Tac in liver transplant patients. The upper panels show the effects of WZC on the Tac blood concentrations (CO, CO/D, and CO/D/W) in patients who took WZC on the 14th day but not on the 7th day after surgery. The $\mathrm{CO}, \mathrm{CO} / \mathrm{D}$, and CO/D/W on day 14 were significantly higher than the respective levels on day 7 in the liver transplant patients. The lower panels illustrate the effects of WZC on the Tac blood concentrations (CO, CO/D, and CO/D/W) in 
patients who took a higher dose of WZC on the 14th day than on the 7th day after surgery. The C0, C0/D, and C0/D/W on day 14 were significantly increased compared with the corresponding levels on day 7 in the liver transplant patients. 